\title{
Transitioning from Curriculum Materials Center to School Library Media Center in Pre-service Teacher Education
}

By Gail Dickinson, Old Dominion University, and

Edna A. Cogdell and Karin Gavigan, University of North Carolina at Greensboro

\begin{abstract}
Pre-service teachers use Curriculum Materials Centers (CMCs) to find resources to use in assignments for college-level pre-service coursework and to use in practice teaching with PK-12 students. CMCs that visually and environmentally resemble school library media centers can transition pre-service CMC users into classroom teachers who use school library media centers for personal professional growth and to enrich their teaching. This article presents a case study of one CMC to illustrate this transition.
\end{abstract}

\section{Introduction}

Curriculum Materials Centers (CMCs) exist in most schools and colleges of education. Their purpose, as stated by the Curriculum Materials Center Collection Development Policy of the Association of College and Research Libraries (ACRL) is to make "readily available for inspection, evaluation, and use, educational materials of the highest quality produced for use with children from preschool age through grade 12 , and adult basic education materials when appropriate to the curriculum" (ACRL, 1993).

One traditional role of CMCs is to act as a warehouse for materials that can be used by pre-service teachers to encourage the development of resource-based teaching. This role is seen as especially important with the current emphasis on accountability in education. As curriculum standards and testing continually change, both pre-service and experienced teachers must select resources to supplement new ways of teaching as well as new content. As early as 1992, Henderson and Barron noted that teachers may lack "the necessary information, resources, and/or skills to respond to the measures under implementation" (Henderson \& Barron, 1992, 254). The CMC can serve as a link for resources and practical applications from pre-service education to use of the school library media center for new and experienced classroom teachers.

CMCs have existed since the 1920s, but the 1960s saw a significant increase in the number of centers, as well as a shift in the types of materials available. The first advent of audiovisual materials in education caused major changes in teacher preparation, along with widespread interest in how teachers were using these materials (Smith \& Ingersoll, 1984). New interest in hands-on learning sparked the development of materials for science and math.

At the same time that school libraries were changing their name and focus into school library media centers, college and university teacher education programs were wrestling with how to organize and access large volumes of oddly shaped materials. These kits, consisting of manipulatives, filmstrips, film loops, and other materials used for experiments, were contained in huge boxes. Storage cabinets for filmstrips, film loops, and tape cassettes began to appear in closets, classrooms, and in faculty offices.

Few academic libraries were prepared to add these materials to their collections. In some cases, the use of the materials required extra space to assemble the materials, or used nonlibrary-adapted messy materials such as water, sand, dirt, or other items. The kits often included filmstrips, film loops, $16 \mathrm{~mm}$ films, and other materials requiring audiovisual equipment that needed to be used in darkened spaces. Manipulative materials and supplies such as construction paper, scissors, and bulletin board materials required special housing as well. Schools and colleges of education slowly began to organize centralized spaces to house the materials, both to institutionalize their use in teacher preparation, and 
to provide more consistent access for all teacher education students.

These rooms were little more than storage space at first, kept under lock and key. Materials, if they were cataloged at all, were organized by accession number or subject area. Eventually, related hardware to view audiovisual materials, and production equipment such as opaque projectors, dry mount presses, and laminators were added to the collections. The curriculum materials center became a different animal than an education library devoted to theory. CMCs were evolving into centers dedicated to practical applications, rather than more research-driven academic facilities such as education libraries.

With the demise of the innovative educational trends of the 1970s and the emergence of the back to basics educational trends in the 1980s, curriculum materials and the centers in which they were housed tended to be on the back burner of teacher education. The materials were still available, and pre-service teachers were encouraged to use them, but very few curriculum materials centers were funded at the level required to keep the materials upto-date.

With the current growing attention to resource-based inquiry learning, curriculum materials centers are once again becoming an active part of teacher education. This is driven in part by the demands of the National Council on the Accreditation of Teacher Education (NCATE) which requires teacher education programs to show how teacher candidates gain access to up-to-date teaching resources, along with data on the funding and use of such resources (NCATE, 2000).

Teclehaimanot and Patterson's 1992 study on the nature, function, and value of curriculum materials centers refers to all of the above in their survey of colleges of education in the north-central U.S. One often overlooked purpose, however, is the value that curriculum materials centers have in creating a resourceaddiction in pre-service classroom teachers. By creating curriculum materials centers that visually resemble school library media centers, pre-service teachers can transition their use of the curriculum materials center to the $\mathrm{K}-12$ school arena. CMC directors who understand the value and purpose of the school library and who can create a model school library media center in a university setting can enhance this transition.

\section{The School Library Media Center}

Teachers are exiting schools of education across the country with toolboxes filled with vast and varied tools to enhance their teaching careers. Some of these teachers have perceptions of school library media centers gained from using a CMC in their teacher preparation program. Others have memories of the school library media centers of their K12 school days.

The school library media profession has the expectation that school library media centers are an extension of the classroom whose goal is to reflect the curriculum and "to ensure that students and staff are effective users of ideas and information" (AASL, 1998).

When teachers visit the school library media center in a school, they can expect to find:

Personnel. Teachers will find a skilled professional library media person capable of assuming the roles of instructional partner, teacher, and information specialist. In addition, the presence of a library media clerk will allow the professional to work more effectively with the teachers.

Books. A collection of print materials that meets the educational and recreational needs of the students and faculty is an essential component of a school library media center. Reference books for research assignments and projects will be needed in all curricular areas. Other print resources to support local, regional, state and national guidelines and standards and professional books that serve as ancillary material for classroom instruction are also reasonable expectations of teachers.

Audiovisual material. Teachers use audiovisual materials to insure that instruction appeals to all learning styles and to capitalize on the heightened visual and sensory awareness of today's students. Videocassette and DVD recordings that support the curriculum are often checked out to enhance instruction. Other audiovisual materials that educators expect to find in the media center are games, maps, globes, kits, sound books, posters and $C D$ 
ROMs. With the new advances in technology, electronic access to encyclopedias, magazine, newspaper and specialized databases also provide easily retrieved information needed by teachers. Internet access is not only expected, but a must.

Technology. Today's educators are required to integrate the use of technology in the instructional process. While not all schools are flush with technology, there is an expectation of some basic equipment. Basic equipment would include: overhead projectors, computers with Internet access, videocassette recorder/players, listening stations (elementary), DVD players, data projectors, laminators, digital cameras, flatbed scanners, and camcorders.

Facility. Teachers expect schools to have a school library media center with functional rooms, furnishings and a student-centered environment. Furthermore, teachers expect students to be able to come to the school library media center as a class, as part of a small group and on an individual basis.

Leadership. Teachers expect school library media specialists to serve as a link between new education reforms and information skills that are required to meet identified needs. School library media specialists will be expected to model and promote lifelong learning.

Special Services. Special services are sometimes unexpected, but always favorably received by teachers. These services, such as assistance with production of instructional or display materials, are varied. Some examples include copier services, laminators, Ellison/Accu-Cut machines for construction paper designs for bulletin boards or wall decorations, staff development for teachers, book fairs, book and/or technology clubs for students, extended hours and evening media nights.

School library media centers and CMCs focus on the same mission in different ways. School library media centers strive to ensure that their K-12 students are effective users of ideas and information, while CMCs have the same mission in their support of teacher education programs. Curriculum Material Centers are learning centers where pre-service teach- ers can analyze and evaluate educational resources for use in student teaching and in their future classrooms.

\section{Case Study: \\ Teaching Resources Center, University of North Carolina at Greensboro}

The national emphasis on information literacy places new demands on the role of Curriculum Materials Centers in the education of preservice teachers. It is imperative that CMCs provide quality curriculum-based resources while, at the same time, providing instruction in accessing and evaluating materials both inhouse and online.

Every effort should be made to guarantee that teacher candidates have positive library experiences when they visit the Curriculum Material Center. These positive encounters help to ensure that pre-service teachers will become active users of school library media centers in their future jobs.

The Teaching Resources Center (TRC) at the University of North Carolina at Greensboro is committed to providing a state-of-the-art, accessible collection of current interdisciplinary resources to meet the needs of the education community at UNCG. In fulfilling this mission, the TRC serves as a model school library media center for pre-service teachers.

Listed below are some ways in which the TRC visually replicates a quality school library media center.

\section{Environment}

The Teaching Resources Center is designed to feel warm and welcoming to students and faculty. The facility itself is located adjacent to the School of Education, and has an outside entrance to a grassy courtyard. Patrons entering the TRC see K-12 instructional books shelved in Dewey Decimal order with a layout much like a school library media center. Posters depicting children's literature and the latest educational websites are located around the room. A Big Book tree, as well as audio books with plush animals, is on display along with an Ellison Machine, videos, CDs and software. 
In collaboration with faculty in the School of Education, the Director of the TRC provides tours to education classes each semester. While touring the Center, students observe a variety of resources available for use in their assignments. They are given a colorful brochure of the TRC that lists the Center's hours, resources, and services. The brochure directs them to the TRC website that provides additional information about the Center. These tours ensure that most of the teacher candidates are exposed to the Center early in their pre-service training.

Students are also given a handout entitled "Net-Worthy Resources for Educators." This webliography helps guide students toward quality educational websites that they can use as teacher candidates and later in their teaching careers. The brochure, the website, and the handout are visual reminders of what resources and services the TRC can provide to pre-service teachers, thus helping to ensure that students move from library tourists to regular patrons of the facility.

\section{Displays}

Displays of TRC materials are changed throughout the year to ensure that patrons are informed about resources available in the Center. Themes for displays have included the Wright Brothers' Centennial, English as a Second Language, the Presidential Election, and seasonal themes. Colorful signage, posters, and other materials enhance the visual appeal of the displays.

Trade books that are used for class assignments are also displayed throughout the year. For example, six sections of a Curriculum and Instruction class entitled Children's Literature and Instructional Media were taught in Fall 2004. The faculty members teaching these classes provided copies of their syllabi to the TRC. This enabled the staff to pull together a display of assignment-related books before the students came to the Center.

One of the showpieces of the TRC is the collection of Award-Winning Materials. This area of the Center includes books that have received the following awards:

- Newbery Award

- Caldecott Award

- ALA Notables
- YALSA's Best Books for Young Adults

- Outstanding Science Trade Books

- Other national awards such as the Coretta Scott King Award, Michael Printz Award, Pura Belpre' and the Sibert International Book Award

- North Carolina Children's Book Award

- North Carolina Battle of the Books

By providing students with opportunities to view award-winning titles, they are able to learn some of the criteria for assessing quality books. Additionally, it provides students with visual applications of their course objectives.

The TRC Director also prepares selective bibliographies of materials available in the Center. These bibliographies are often prepared at the request of the faculty. For example, a professor in the Specialized Education Services (SES) department requested a bibliography of "Books for Children and Young Adults About Individuals with Special Needs." The books listed in this bibliography are on display for students to use for SES assignments. Since the books are on display yearround, several students who are not SES majors have checked these titles out.

\section{Seeing is Believing}

American Library Association (ALA) defines information literacy as "the set of skills needed to find, retrieve, analyze, and use information"(ALA, 1998). The 2000 NCATE standards specify that candidates preparing to work in schools must be able to integrate information literacy into the P-12 curriculum appropriately and effectively to support student learning (NCATE, 2000).

Given these standards, it is imperative that teacher preparation programs provide opportunities for their students to be exposed to a model school library media environment that effectively integrates information literacy.

The Teaching Resources Center at UNCG provides a visual interpretation of a school library media center on a college campus. What better model for pre-service teachers to encourage resource-based teaching and personal professional growth than Curriculum Materials Centers? 


\section{Conclusion}

The relationship between school library media centers in K-12 schools and curriculum materials centers in schools and colleges of education has distinct parallels. Both have the role of encouraging resource-based instruction, encouragement of reading, and the effective use of technology in instruction. A review of Lare's works on the management of curriculum materials centers indicate that school library management texts are often cited as a program administration and management guide (Lare, 1997, 2004).

In the above case study, the parallels between elements of a typical school library media program that classroom teachers can expect to find in schools and the Teaching Resource Center at UNCG were a conscious choice. Organizing the $\mathrm{CMC}$ to assist preservice teachers in the same way that school library media centers will assist them as they begin their careers as educators places the $\mathrm{CMC}$ in the center of the pre-service education program.

O'Hanlon notes in her research on library instruction in academic libraries that "Educators generally acknowledge that elementary and secondary school teachers profoundly influence pupils' attitudes toward learning and use of educational resources such as libraries" (O'Hanlon, 1988, 34). An important role for the curriculum materials center is to guide pre-service teachers to rely on the resources and services that curriculum materials centers and school library media programs offer.

Information Power: Building Partnerships for Learning

Mission and Goals of the School Library Media Program

The mission of the library media program is to ensure that students and

staff are effective users of ideas and information. This mission is accomplished:

* by providing intellectual and physical access to materials in all formats

* by providing instruction to foster competence and stimulate interest in reading, viewing, and using information and ideas

* by working with other educators to design learning strategies to meet the needs of individual students.

\section{References}

American Association of School Librarians/Association for Educational Communications and Technology. (1998). Information power: Building partnerships for learning. Chicago: American Library Association.

American Library Association. (1989). Presidential committee on information literacy: Final report. Chicago: American Library Association.

Association of College and Research Libraries. (1993). Model collection development policy. Chicago: American Library Association.

Carr, Jo Ann, ed. The Nature, Function, and Value of the Curriculum Materials Center in Colleges of Education. (Chicago, III., American Library Association, 2001.)

Henderson, M., \& Barron, B. (1992, Winter). Expanding the role of the curriculum materials center: challenges for the $21^{\text {st }}$ century. Education, 113, 254-255.

Ho, M. (1985). Competencies of curriculum materials center directors in teachereducation institutions. Association for Educational Communication and Technology. Proceedings.

Lare, G. (1997). Acquiring and organizing curriculum materials: A guide and directory of resources. Lanham, MD: Scarecrow.

Lare, G. (2004). Acquiring and organizing curriculum materials: $A$ guide and directory of resources. $\left(2^{\text {nd }}\right.$ ed.). Lanham, MD: Scarecrow.

National Council for the Accreditation of Teacher Education. (2000). Unit Standards. Washington, D.C., NCATE.

O'Hanlon, N. (1988, Summer). Up the down staircase: Establishing library instruction programs for teachers. Research Quarterly, 27, 528-534.

Smith, C., \& Ingersoll, G. (1984, Sept.). Audiovisual materials in U.S. schools: A national survey on availability and use. Educational Technology, 24(9), 36-38.

Teclehaimanot, B., \& Patterson, A. (1992, Feb.). The nature, function, and value of the curriculum materials center in colleges of education. Association for Educational Communication and Technology. Proceedings. 